\title{
A Quantitative Research on the Xenophobia Examination in Terms of Psychological Resilience: Case of Istanbul
}

\author{
Ahmed Taha Arifoglu ${ }^{1 *}$ (), Orhan Kocak ${ }^{1}$ (1)
}

${ }^{1}$ Istanbul University-Cerrahpasa, Istanbul, TURKEY

*Corresponding Author: ataharifoglu@gmail.com

Citation: Arifoglu, A. T. and Kocak, O. (2022). A Quantitative Research On The Xenophobia Examination In Terms of Phychological Resilience: Case of Istanbul. European Journal of Environment and Public Health, 6(1), em0105. https://doi.org/10.21601/ejeph/11803

\begin{tabular}{ll}
\hline ARTICLE INFO & $\begin{array}{l}\text { ABSTRACT } \\
\text { Received: 1 Jan. 2022 }\end{array} \quad \begin{array}{l}\text { Xenophobia can be defined as negative prejudice towards strangers. It can also be defined as the hatred of } \\
\text { foreigners. Psychological resilience is an independent source of resistance and a personality-based tendency to } \\
\text { mitigate and overcome the effects of a stressful life. Psychological resilience has three dimensions; commitment, } \\
\text { control, and challenge. A review of xenophobia, in terms of psychological resilience, has not been examined yet. } \\
\text { This study examines the xenophobic opinions and attitudes of Turkish citizens living in Istanbul against more } \\
\text { than } 4 \text { million immigrants with various legal status in Turkey in terms of psychological resilience. As a result of } \\
\text { the study, it was observed that psychological resilience did not function as resistance against xenophobia. This } \\
\text { result is obtained since two of the three factors representing psychological resilience strengthen the xenophobia. }\end{array}$ \\
&
\end{tabular}

Keywords: psychological resilience, Syrians, immigrants, xenophobia

\section{INTRODUCTION}

In the transition from traditional society to modern society, psychological changes that influence human nature have been occurred. With capitalism, which constitutes the economic structure of modern society, the idea of efficiency and skillfulness has been regarded as the most significant moral virtues in the intellectual sense. The sense of relative security and belonging provided to the individual by the traditional social structure has eroded (Fromm, 2011). There is no natural and definite fixed place allocated in the economic and social order; the individual is left alone in modern society. Everything has become dependent on his/her effort of the individual, not the security provided by his/her traditional position. Everyone is a potential rival in modern society. Consequently, a person's relationship with the people in society is an enemy and foreign relationship (Bauman, 2014). Although individuals of this society are in a distant and competitive relationship with each other in daily life, the consciousness of "we" is established differently.

We consciousness is a contract that governs social relations. The newcomer to this society is not included in us; the newcomer represents an uncertainty against we consciousness and is perceived as foreign. As newcomers to society represent social uncertainty in this modern order where competition is established, a source of concern is also an instrument of resentment as they are regarded as rivals in that society without being included in the contract, resulting from "we" consciousness. For the newcomer to be included in "we" consciousness, it is necessary to include him/her socially in everyday life. If this cannot be overcome healthily, it will bring competitiveness and conflict against the newcomer perceived as foreign. Competitiveness and dominance target the source of disturbance in the modern individual; this prevents the individual from feeling worried and insecure. (Hermann, 2019). Competition and dominance are combined with a low tolerance level in the individual (Hermann, 2019). Low tolerance makes the individual intolerant of others who are not like him/her. The inclusion of the foreigner by society implies psychological resilience. Psychological resilience is a personality-based tendency that turns uncertainty and stress in its favor and increases tolerance in social relationships. In this context, the study's purpose searches the xenophobic ideas and attitudes against 4 million immigrants living under different legal statuses in Turkish society in the weakness of psychological resilience, also serving as the social resistance.

It is the advanced version presented as a summary at the International Symposium “Global Migration Phenomenon” With Its Security, Economic, Social, Political and Cultural Dimensions. 


\section{LITERATURE REVIEW}

\section{Syrians Under “Temporary Protection" in Turkey and Turkish Society}

Turkey is one of the top countries that Syrian citizens immigrate due to the civil war that began in March 2011 in Syria. The number of Syrians under temporary protection status in Turkey is equal to 3 million 600 thousands and 710, according to the numbers issued in July 2020 (Refugees Association, 2020). In a study conducted about the young Syrians living under temporary protection status, the young people believe that they are experiencing social exclusion patterns in the public sphere, and it is related to the fact that they are "Syrian" (Sunata, 2019). One of the social exclusion patterns discussed is the perception that they cannot rent a house because they are Syrian, they are harassed, they are not taken care of in official offices, they are not enrolled in schools, they are excluded from school, they are maltreated at work, and that they work in more inferior conditions than Turkish citizens (Sunata, 2019). Several studies have also proved the Syrian community's social exclusion patterns; while 4 out of 10 Turkish citizens approve of neighbor or friendship relations with Syrians in the same neighborhood, 1 out of 10 people approve to share the same house or family (KONDA, 2016). According to another study investigating the dimension of social exclusion in their daily lives, Syrians believe that they encounter discriminatory and insulting language in the public sphere. Hence, they feel that they are stigmatized continuously in their daily lives (Kucuksen, 2017). Turkish society's perception of cultural similarity with Syrians is declining, and social distance is gradually increasing; the citizens distance themselves from living together with Syrians (Erdogan, 2020). Recent studies indicate that this problem is becoming more critical. In the survey conducted by Istanpol in 2020 , participated by Turkish citizens, $62 \%$ of the participants declared that they encountered Syrians in public places, $17 \%$ lived in the same building, and $78 \%$ did not communicate with Syrians. All participants affirmed that they consider Syrians as the third most significant problem of İstanbul (Istanpol, 2020).

Turkish society was determined to avoid constant social contact with the Syrian community under temporary protection (Istanpol, 2020). Based on these studies' results, it is evaluated that Syrians are not involved in society, and there is a lack of harmony between the Syrian community and the Turkish community. This discrepancy is based on the fact that Turkish society does not include Syrians under temporary protection status in the "we" consciousness. In this context, the Turkish society's behaviors of avoiding constant social interaction with the Syrian community in their daily life practices, not comprehending any cultural affinity; perceptions of social distance can also be considered as a failure of the social cohesion programs carried out through various non-governmental organizations and governmental institutions between the host and the guest community. Hence, seeking the Turkish society's xenophobic attitudes and thoughts towards immigrants in their psychological resilience will help understand this issue. Developing social programs based on psychological resilience will be essential in preventing the increasing xenophobia against immigrants representing over 4 million Syrians under temporary protection status.

\section{Xenophobia and Psychological Resilience}

Modern social theory creates a separate group of people who live in peace with each other, as in traditional community theory, this time is not fundamentally connected, contrary to traditional theory. While they continue together despite everything that separates the traditional from each other, the modern one remains separate despite everything that connects each other (Tönnies, 2019). The period described as modernity led to many contradictions. Laws, patterns, and rules that people can voluntarily obey and consider as reliable have decreased (Balandier, 2018). The sense of belonging that feudal communities offer to individuals has become meaningless for modern society. This period takes the idea that the individual's position in society is defined by external influences, as in medieval philosophy, and substitutes the idea of self-management in which the human determines his/her destiny. Consequently, the individual cannot blame anyone for the misery, s/he cannot blame the failure on anything other than his/her slackness and laziness, and is always in a position to seek no remedy other than striving harder (Bauman, 2017). Modernity also always encourages the individual to compete and struggle to avoid uncertainty and insecurity. In this society, "we" consciousness is created by society members through mutual relations, behaviors, and values (Mupotsa and Kreutzfeldt, 2016). At the same time, modern society seeks to establish its internal reference system by categorizing its members into "us" and "them", and the sum of attributes considered to be ordinary and natural for the members of each category establishes what constitutes "us". In other words, these qualities determine the categories of people likely to be encountered in the social issues they point out and strive to overcome the uncertainty inherent in modern society (Goffman, 2014).

When we meet a foreigner, it is possible to predict his/her social identity in advance. The foreigner is the indeterminate one that is not included in our category. Accordingly, in such a society, every individual who is not in the usual interaction process and practice is a candidate to be seen as "them", in other words, as a foreigner (Rutherford, 2007). The vast majority of xenophobia is based on ethnic differences, in other words, racism (Harcourt, 2009; Nyamnjoh, 2010). Hostility is defended by the perpetrator who feeds this feeling, without exception, based on group differences (Allport, 2016). This situation leads to the concept of psychological resilience.

Psychologically resilient people are considered to evaluate potentially stressful events differently than nonpsychologically resilient people and are more resistant to the possibly damaging effects of stress (Sinclair \& Tetrick, 2000). In this context, it is reasonable to comprehend psychological resilience in society as a function that prevents xenophobia and, consequently, increases society's social inclusion capacity. This concept is a personality-based tendency to reduce stressful life events and includes optimistic cognitive evaluations and deterministic coping actions. Psychological resilience serves a beneficial function; commitment, control, and challenge determine an individual's perceptions of himself/herself and his/her interaction with the environment. 
Hence, resilience has common grounds with several theoretical factors on mental health (Maddi and Khoshaba, 1994).

Xenophobia is a negative prejudice against the stranger and is associated with mental health. Consequently, xenophobia is closely related to social, mental health, and factors affecting migrants' social inclusion. In this respect, the weakness of psychological resilience helps to explain xenophobia. Psychological resilience attitudes as a whole structure how the individual thinks about their interactions with the world they live in and provide motivation to surmount challenging things they encounter in life (Maddi, 2002).

The separation of the concept of resilience into three subdimensions causes some concerns. Most importantly, the combination of different dimensions in one concept, psychological resilience, leads to a significant loss of information to explain how resilience relates to other structures (Sinclair and Tetrick, 2000). Hence, in this study, sub-dimensions of psychological resilience were taken as a reference and compared with xenophobia in order to thoroughly understand the relationship.

\section{Commitment}

Among people under stress, those who feel attached in various areas of their lives remain healthier than those who are alienated. People with powerful self-commitment have a belief system that minimizes the perceived threat of any stressful life event. This factor's high level provides an accurate assessment of the threat posed by a particular life situation. The commitment factor prevents the individual from avoiding establishing a social relationship with other people when faced with a stressful environment (Kobasa, 1979). From this perspective, it is considered to play an essential role in explaining xenophobic attitudes and thoughts.

People with high commitment find themselves and their environment interesting and valuable (Sinclair and Tetrick, 2000). Attached people can find things that satisfy their curiosity in everything (Isik, 2016; Sinclair and Tetrick, 2000). People with high commitment rely on themselves to transform everything they experience into something interesting and essential rather than alienating it (Maddi and Khoshaba, 1994). People with low commitment are not interested in other people, events, and things (Maddi, 2002). People with low commitment pull back and isolate themselves in the face of this situation instead of interacting with their environment (Maddi et al., 2006). The absence or lack of feelings, thoughts, and behaviors represented by commitment in society prepares the ground for developing xenophobic attitudes and thoughts.

\section{Challenge}

Among people under stress, those who consider changing a challenge remain healthier than those who perceive change as a threat. People who think positively about transformation are catalysts of change in their entourage and have experience in responding to unexpected situations. People who perceive change as a challenge tend to be cognitively flexible as they value life full of interesting experiences, and they comprehend what resources to use to help them cope with stress. In this way, they can adequately evaluate the threats they encounter (Kobasa, 1979).
The challenge signifies the belief that change is a natural part of everyday life (Isik, 2016). The reason why people with a high level of challenge factor perceive the change as promoting development is their belief that they can rearrange their situations (Isik, 2016). People with a high challenge factor add meaning by learning rather than choosing and spending their lives easy, comfortable, and safe (Maddi, 1990; Sinclair and Tetrick, 2000). People with a strong level of challenge do not believe they have a right to easily acquired safety and comfort. They perceive change as a natural process and opportunity through both positive and negative experiences (Maddi et al., 2006).

\section{Control}

Control increases the stress resistance by ensuring the likelihood of events occurring as a natural consequence of one's actions and thus not perceiving the stranger as unexpected and devastating experiences (Kobasa et al., 1982). Control is the search for interpretation and analysis in the face of stressful events fronted by an individual. In terms of coping, the control factor leads to actions directed at turning events into something consistent with an ongoing life plan (Kobasa et al., 1982). Control is also responsible for developing a comprehensive and varied repertoire of responses to stress, and the presence of a sense of control in the individual makes the most dangerous conditions s/he faces (Kobasa et al., 1982). People with essential control levels believe that they can influence what happens around them by making an effort (Maddi, 1990; Sinclair and Tetrick, 2000). Among people under stress, those who have a high level of control always remain healthy against those who feel powerless in the face of external forces no matter what happens in their lives. A highly stressed but healthy person is considered to have three different abilities:

1. having control of decision making or the ability to autonomously choose between various modes of action to address stress,

2. having the ability to cognitive control or to interpret, evaluate and incorporate various stressful events into an ongoing life plan and thus deactivate their shocking effects, and

3. coping skills or are deemed to have appropriate responses to stress developed through a characteristic motivation to achieve resolution of all stressful situations.

People with a low level of control but a high level of stress are nihilistic, and their motivation for success is low (Kobasa, 1979). This increasing xenophobia and racism that develops accordingly cause vulnerability and abuse for those labeled as foreigners in that society. With a comprehensive perspective, xenophobia prevents human equality, social justice, and social cohesion (Crush and Ramachandran, 2009). From this perspective, understanding from a psychological perspective of growing xenophobia in Turkey can play a guiding role in planning social cohesion programs between host and host communities. 
Table 1. Socio-demographic frequency analysis of participants

\begin{tabular}{|c|c|c|c|}
\hline Variable & Value & $\mathbf{N}$ & $\%$ \\
\hline \multirow{2}{*}{ Gender } & Female & 247 & 42.3 \\
\hline & Male & 337 & 57.7 \\
\hline \multirow{2}{*}{ Marital status } & Single & 404 & 69.2 \\
\hline & Married & 180 & 30.8 \\
\hline \multirow{3}{*}{ Employment status } & Employed & 244 & 41.8 \\
\hline & Not working & 300 & 51.4 \\
\hline & Unemployed & 40 & 6.8 \\
\hline \multirow{7}{*}{ Age category } & Between $18-25$ years old & 264 & 45.2 \\
\hline & Between $26-30$ years old & 71 & 12.2 \\
\hline & Between $31-35$ years old & 50 & 8.6 \\
\hline & Between $36-40$ years old & 51 & 8.7 \\
\hline & Between $41-45$ years old & 45 & 7.7 \\
\hline & Between $46-50$ years old & 37 & 6.3 \\
\hline & 51 years and older & 66 & 11.3 \\
\hline \multirow{5}{*}{ Educational level } & High school graduate & 47 & 8.0 \\
\hline & University student & 244 & 41.8 \\
\hline & University graduate & 172 & 29.5 \\
\hline & Postgraduate student & 58 & 9.9 \\
\hline & Postgraduate degree & 63 & 10.8 \\
\hline \multirow{4}{*}{ Monthly income } & Between 0-2,324 TL & 301 & 51.5 \\
\hline & Between 2,325-4,999 TL & 127 & 21.7 \\
\hline & Between 5,000-7,228 TL & 115 & 19.7 \\
\hline & 7,229 TL and above & 41 & 7.0 \\
\hline
\end{tabular}

Note. TL: Turkish Lira

\section{RESEARCH AND METHOD}

\section{Research Problem}

The aim of the study is to investigate the source of the failure of psychological resilience to serve as the resistance for the increasing xenophobic opinions and attitudes in Turkish society against more than 4 million immigrants, living under different legal status in Turkey.

\section{Duration of the Study}

This study started in February 2020 and was completed in June 2020. The article was written in September 2020.

\section{Limitations of the Study}

This study has three limitations.

1. Many people have migrated to Turkey for various reasons and live under various legal statuses. The term 'immigrant' has been preferred for these people in order to prevent confusion.

2. In this study, the immigrants constitute Turkish society's perceptions of living in Istanbul towards Syrians under temporary protection status.

3. In this research, the resistance function of psychosocial resilience signifies a situation where the level of xenophobia decreases in the face of each factor mentioned, while the commitment, control, and challenge factors increase.

\section{Research Hypotheses}

This study has one hypothesis, as follows: In Turkish society living in Istanbul, psychological resilience does not function as resistance against xenophobia.
Research Method, Measurement Tools, Universe, and Sampling

Psychological and sociodemographic scales were applied to the participants through google questionnaires. The research sample consists of a total of 584 randomly selected participants, 247 women and 337 men, between the ages of 1875. Table 1 shows socio-demographic frequency analysis of participants. The universe of the research is the city of Istanbul. The sample size was determined with a 95\% confidence interval and a $5 \%$ margin of error. This study was carried out utilizing the survey technique via internet-based google forms. SPSS and JASP programs analyzed the study data of 584 people. Regression analysis and mediator variable analysis were used as analysis methods.

\section{Measurement Tools \\ Personal information form}

The researcher prepared this form as a data collection tool to collect information about the participants' socio-cultural and demographic characteristics.

\section{Xenophobia scale}

The xenophobia scale used in this study was developed by van der Veer et al. (2011). The original xenophobia scale consists of 14 items and is 6-point Likert type. Turkish validity and reliability studies have been conducted at national level (Ozmete et al., 2018). The lowest score that can be obtained from the scale is 11 , the highest score is 66 , and a more significant score means that the risk of xenophobia increases. Cronbach alpha value is .876 .

\section{Psychological resilience scale}

This scale was developed by Kobasa (1979). Isik (2016) carried out the development, validity, and reliability study of the Turkish form. Psychological resilience scale consists of 21 items and three sub-dimensions. These dimensions have been named as the commitment, control, and challenge following the literature. The three-factor structure of the scale was confirmed by confirmatory factor analysis. Also, the differences between the means of the $27 \%$ lower and upper groups in the scale items were significant. The Cronbach alpha value for the entire scale was found to be between .62 and .74 (Isik, 2016).

\section{Reliability Analysis}

Cronbach's alpha and KMO values, which were obtained with the answers given to the xenophobia scale by the participants in the study, are.923 and .942, respectively. Cronbach's alpha and KMO values in general of the psychological resilience scale are .835 and .887 , respectively. Cronbach's alpha and KMO values of the commitment factor among the sub-dimensions are .698 and .763 , respectively. The Cronbach's alpha and KMO value of the challenge factor are .794 and .846 , respectively. The Cronbach's alpha and KMO value of the control factor are .641 and .730 , respectively. 
Table 2. Descriptive statistics of the xenophobia scale

\begin{tabular}{lccccc}
\hline & N & Min. & Max. & Mean & SD \\
\hline Xenophobia total & 581 & 11.00 & 66.00 & 46.2272 & 11.40856 \\
\hline Valid N (listwise) & 581 & & & & \\
\hline
\end{tabular}

Note. SD: Standard deviation

Table 3. Descriptive statistics of the factors of the psychological resilience scale

\begin{tabular}{lccccc}
\hline & N & Min. & Max. & Mean & SD \\
\hline fac1_challenge & 584 & 1.00 & 5.00 & 4.1370 & .54226 \\
\hline fac2_commitment & 584 & 1.25 & 5.00 & 3.5569 & .73292 \\
\hline fac3_control & 584 & 1.60 & 5.00 & 3.6466 & .48087 \\
\hline
\end{tabular}

Valid N (listwise) 584

Note. SD: Standard deviation

\section{FINDINGS AND COMMENTS}

3 out of 584 participants did not answer the xenophobia scale. The mean xenophobia scale of 581 respondents was determined as 46.22 . Table 2 depicts the descriptive statistics of the xenophobia scale. The descriptive statistics of the psychological resilience sub-dimension of the participants are presented in Table 3.

Findings and Comments on the Investigation of the Relationship Between Psychological Resilience SubDimensions and Xenophobia

In terms of the relationship between resilience subdimensions and xenophobia, it has been determined that the dependent variable is xenophobia; the independent variable is the dimensions of commitment, challenge, and control, it was examined by the regression analysis method that $\mathrm{p}<.05$ was considered significant (Table 4).

The resistance function of psychosocial resilience signifies a situation where the level of xenophobia decreases in the face of each factor mentioned, while the commitment, control, and challenge factors increase. In this study, the increase in challenge and control also increase xenophobia, while the increased commitment decreases xenophobia. Two of the three factors that should reduce xenophobia increase xenophobia; this situation points to a problem. The common theme of the two factors mentioned is the effort to resolve uncertain and worrying situations. People with a high level of control seek to interpret and resolve stressful events they encounter. People with a strong challenge factor have experience in responding to unexpected situations. There may be many reasons for this result, but the main reason in this study is considered to be the migration management that started with the 2011 Syrian Civil War. The Turkish government has stated that Syrians have been guests for a long time and will return to their country (bianet, 2018; DW, 2018; Hurriyet, 2014; NTV, 2012). This discourse built on temporary status has been accepted by Turkish society (KONDA, 2016). Nevertheless, as time progressed, it was perceived in the public opinion that Syrians became permanent (Cumhuriyet, 2018).

Although this discourse, built based on temporary status, provided successful results in the first years, it generated various problems in the following years. Various academic
Table 4. Regression analysis

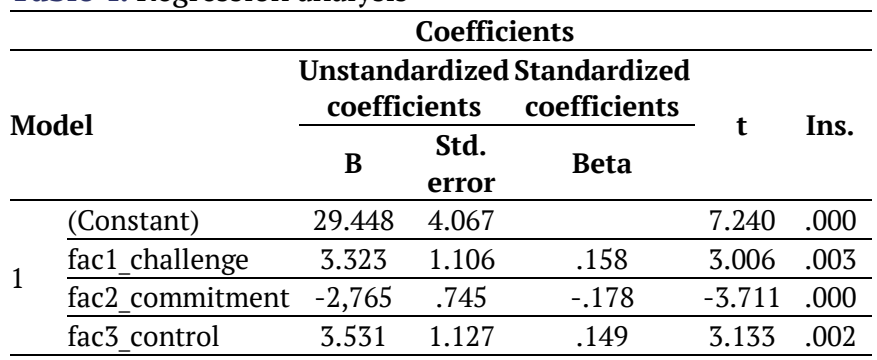

Dependent variable: Xenophobia total

studies on this subject shed light on the subject. In 2014, a study measuring the perception of the Turkish community against Syrians indicated that $72.2 \%$ of citizens in Turkey regarded them as "our guests, our religious fellows, people escaping from oppression” (Erdogan, 2014). However, as time progresses and the permanence tendency in the field increases, the perceptions against the Syrians have started to change in Turkish society. The study published by Istanpol in 2019 showed that the Syrians became "one of Turkey's most important problem” in Turkey (Istanpol, 2019). In Erdogan's (2019) study published in 2019, it was stated that the Turkish society believed that Syrians would return, and when this belief disappeared, reactions exaggerated. Turkish society's tendency to think that Syrians are no longer victims of war is getting stronger (Istanpol, 2020).

The social acceptance established on temporary status and Syrians' increasing permanence tendency under temporary protection status signifies two different Turkish society perceptions, which leads to a contradiction. While the challenge and control factors increase, at the same time increasing xenophobia should be considered as a rationalization effort in the context of cognitive conflict (Aronson, 1969). The experience of Turkish society with Syrians is based on "guest" perception; the permanence of Syrians is a new experience. This cognitive contradiction increases xenophobia. At the same time, this prevents resilience from acting as a resistance against xenophobia. This increase in xenophobia in cognitive conflict is the cause of xenophobic attitudes and thoughts in society.

A new migration management paradigm in line with the reality in the field is necessary for Turkish society and Syrians under temporary protection to create a life together. This will also strengthen the potential of Turkish society and immigrants to live together. In this context, it is evaluated that the xenophobic tendencies in Turkish society will also decrease. The data providing this inference is the decrease in xenophobia, while the commitment factor increases. People with low commitment pull back and isolate themselves in the face of this situation instead of interacting with their environment (Maddi et al., 2006). In this context, the tendency of Turkish society to socially interact with immigrants is strong. Analysis of mediator variables was conducted to prove the strength of this trend. In the analysis showing the commitment factor in Table $\mathbf{5}$ is the mediator variable; the combined effect of mediating variable and independent variables decreases xenophobia. It has also been observed that resilience can potentially act as resistance. 
Table 5. Mediator variable analysis indirect effects

\begin{tabular}{|c|c|c|c|c|c|c|c|c|}
\hline & & & & & & & $5 \%$ conf & e interv \\
\hline & & & Estimate & Std. error & z-value & p-value & Lower & Upper \\
\hline fac3_control & $\rightarrow$ fac2_commitment & $\rightarrow$ XenophobiaTotal & 0.427 & 0.207 & -2.064 & 0.039 & -0.833 & -0.022 \\
\hline fac1_challenge & $\rightarrow$ fac2_commitment & $\rightarrow$ XenophobiaTotal & -1.780 & 0.502 & -3.547 & $<.001$ & -2.763 & -0.797 \\
\hline
\end{tabular}

Note. Delta method standard errors, normal theory confidence intervals, ML estimator

Commitment is the tendency to interact socially. This tendency is strong in Turkish society against xenophobia. The mediator variable's effect, together with the independent variables, decreases xenophobia by -0.427 and -1.780 points, respectively. This situation also represents a potential for Syrians under temporary protection and Turkish society to live together. The obstacle to this potential is the result of failed migration management. This result creates cognitive contradiction and strengthens xenophobic attitudes and thoughts in society. The result of this study shows that Turkish society has a high potential to live with immigrants. The realization of this potential depends on the migration management paradigm in line with the field's reality. Nongovernmental organizations, academicians and policy makers will be needed more than ever to implement this paradigm.

\section{CONCLUSIONS AND RECOMMENDATIONS}

This study concludes that resilience does not function as resistance against xenophobia. The fact that resilience does not function as resistance against xenophobia is a result of cognitive conflict. This is represented by the relationship between the independent variables of challenge and control factors and the dependent variable xenophobia. The experience of Turkish society with Syrians is based on "guest" perception. The permanence of Syrians is a new experience. This experience leads to a cognitive conflict. This contradiction is the result of the migration management built based on temporary status, which is contrary to reality.

Xenophobic attitudes and thoughts in Turkish society are a consequence of cognitive conflict. A new, sustainable, consistent migration management paradigm is required to build Turkish society and immigrants' coexistence. Turkish society's potential to live with immigrants is strong, but current migration management reduces this potential. This inference is based on the fact that as the challenge and control factors rise, xenophobia increases, while the commitment factor decreases xenophobia. In this context, Turkish society and Syrians under temporary protection have a high potential to live together. Nevertheless, the transformation mentioned in migration management must be experienced to achieve this.

Author contributions: All co-authors have involved in all stages of this study while preparing the final version. They all agree with the results and conclusions.

Funding: No external funding is received for this article.

Declaration of interest: The authors declare that they have no competing interests.

Ethics approval and consent to participate: Not applicable.

Availability of data and materials: All data generated or analyzed during this study are available for sharing when appropriate request is directed to corresponding author.

\section{REFERENCES}

Allport, G. (2016). Önyargının doğası [The nature of prejudice], N. Nirven (trans.). Sakarya: Sakarya Üniversitesi Kültür Yayınları [Sakarya University Cultural Publications].

Aronson, E. (1969). The theory of cognitive dissonance: A current perspective. Advances in Experimental Social Psychology, 4, 1-34. https://doi.org/10.1016/S00652601(08)60075-1

Balandier, G. (2018). Büyük rahatsızllk [The great inconvenience], D. Cetinkasap (trans.). Istanbul: İş Bankası Kültür Yayınları [Isbank Cultural Publications].

Bauman, Z. (2014). Modernlik ve müphemlik [Modernity and ambivalance], I. Turkmen (trans.). Istanbul: Ayrintı Yayınevi [Ayrinti Publishing House].

Bauman, Z. (2017). Akışskan modernite [Liquid modernity], S. O. Cavus (trans.). Istanbul: Can Yayınlar1 [Can Publications].

bianet. (2018, January 29). Erdogan: Purpose of Afrin operation is to send Syrians home. Available at: http://bianet.org/ english/militarism/193774-erdogan-purpose-of-afrinoperation-is-to-send-syrians-home

Crush, J. and Ramachandran, S. (2009). Xenophobia, international migration and human development. Journal of Human Development and Capabilities, 11(2), 209-228. https://doi.org/10.1080/19452821003677327

Cumhuriyet. (2018, November). Gerçekle yüzleşin: Savaş bitse de kalıclar [Face the truth: Even the war is over, they will stay]. Available at: http://www.cumhuriyet.com.tr/haber/ turkiye/1132275/Gercekle_yuzlesin_Savas_bitse_de_kalici lar.html

DW. (2018, March). With Turkey's offensive into Afrin, Erdogan is seeking to kill two birds with one stone. Available at: https://www.dw.com/en/with-turkeys-offensive-intoafrin-erdogan-is-seeking-to-kill-two-birds-with-onestone/a-42803519

Erdogan, M. (2014). Türkiye’deki Suriyeliler: Toplumsal kabul ve uyum araştırması [Syrians in Turkey: Social acceptance and cohesion research]. HUGO. Available at: http://www.hugo.hacettepe.edu.tr/

Erdogan, M. (2019, September). Türkiye’deki Suriyeli mülteciler [Syrian refugees in Turkey]. Konrad Adenauer Stiftung. Available at: https://www.kas.de/documents/ 283907/7339115/Türkiye\%27deki+Suriyeliler.pdf/acaf9d37 $-7035-f 37 c-4982-c 4 b 18 f 9 b 9 c 8 e$ ?version $=1.0 \& t=$ 1571303334464

Erdogan, M. (2020). Suriyeliler barometresi 2019, Suriyelilerle uyum içinde yaşamın çerçevesi [Syrians barometer 2019, framework for living in harmony with Syrians]. Ankara: Orion Kitabevi [Orion Publishing House]. 
Fromm, E. (2011). Özgürlükten kaçış [Escape from freedom], S. Yegin (trans.). Istanbul: Payel Yayınevi [Payel Publishing House].

Goffman, E. (2014). Damga, örselenmiş kimliğin idare edilişi üzerine notlar [Stigma, notes on the management of spoiled identity], L. Unsaldı, S. Genis and S. N. Agirnasli (trans.). Ankara: Heretik Yayıncılık [Heretik Publishing].

Harcourt, W. (2009). Editorial: Racism, xenophobia and development. Society for International Development, 52(4), 441-444. https://doi.org/10.1057/dev.2009.79

Hermann, H. (2019). Insanlarda ve hayvanlarda baskınlı ve saldırganlık, büyük yaşam mücadelesi [Dominance and agression in humans and other animals], G. Bir (trans.). Istanbul: The Kitap Yayınları [The Kitap Publishing].

Hurriyet. (2014, October 8). Erdoğan Suriyeli sığınmacılara seslendi [Erdogan addressed the Syrian refugees]. Available at:https://www.hurriyet.com.tr/gundem/erdogan-suriyelisiginmacilara-seslendi-27342780

Isik, S. (2016). Psikolojik dayanıklılık ölçeği’nin geliştirilmesi: Geçerlik ve güvenirlik çalışması [Developing the psychological hardiness scale: The validity and reliability study]. The Journal of Happiness \& Well-Being, 4(2), 165182.

Istanpol. (2019). 24 Haziran'dan 31 Mart'a iki seçim arası Türkiye'de siyasal kutuplaşma [Political polarization in Turkey between the period of the two elections: June 2018 and March 2019]. Istanpol. Available at: https://www.istanpol.org/post/24-haziran-dan-31-marta-i-ki-se\%C3\%A7im-aras\%C4\%B1-t\%C3\%BCrkiye-desiyasal-kutupla\%C5\%9Fma

Istanpol. (2020). İstanbul'da Suriyeli sığınmacılara yönelik tutumlar [Attitudes towards Syrian refugees in Istanbul]. Istanpol. Available at: https://www.istanpol.org/post/ i\%CC\%87stanbul-da-suriyeli-s\%C4\%B1\%C4\%9F\%C4\% B1nmac\%C4\%B1lara-y\%C3\%B6nelik-tutumlar

Kobasa, S. C. (1979). Stressful life events, personality, and health: An inquiry into hardiness. Journal of Personality and Social Psychology, 37(1), 1-11. https://doi.org/10.1037// 0022-3514.37.1.1

Kobasa, S. C., Maddi, S. R. and Kahn, S. (1982). Hardiness and health: A prospective study. Journal of Personality and Social Psychology, 42(1), 168-177. https://doi.org/10.1037/ 0022-3514.42.1.168

KONDA. (2016). KONDA barometresi, temalar, Suriyeli sığınmacılara bakış [Themes, overview of Syrian refugees]. KONDA. Available at: https://konda.com.tr/tr/rapor/ suriyeli-siginmacilara-bakis/

Kucuksen, K. (2017). Suriyeli sığınmacı kadınlarda sosyal dışlanma algısı üzerine nitel bir çalışma [A qualitative study on the perception of social exclusion in Syrian refugee woman]. Insan ve Toplum Bilimleri Araştırmalar Dergisi [Journal of Human and Social Sciences Research], 6(5), 2399-2413.

Maddi, S. R. (1990). Issues and interventions in stress mastery, in H. S. Friedman (ed.), Personality and disease (121-154). New York: John Wiley \& Sons.
Maddi, S. R. (2002). The story of hardiness: Twenty years of theorizing, research, and practice. Consulting Psychology Journal: Practice and Research, 54(3), 175-185. https://doi.org/10.1037/1061-4087.54.3.173

Maddi, S. R. and Khoshaba, D. M. (1994). Hardiness and mental health. Journal of Personality Assessment, 63(2), 265-274. https://doi.org/10.1207/s15327752jpa6302_6

Maddi, S. R., Harvey, R. H., Khoshaba, D. M., Lu, J. L., Persico, M. and Brow, M. (2006). The personality construct of hardiness, III: Relationships with repression, innovativeness, authoritarianism, and performance. Journal of Personality, 74(2), 576-597. https://doi.org/ 10.1111/j.1467-6494.2006.00385.x

Mülteciler Derneği [Refugees Association]. (2020, July 23). Türkiyedeki Suriyeli sayısı Temmuz 2020 [Number of Syrians in Turkey, July 2020]. Available at: https://multeciler.org.tr/ turkiyedeki-suriyeli-sayisi/

Mupotsa, D. and Kreutzfeldt, D. (2016). Xenophobia, nationalism and techniques of difference. Agenda, Empowering Women for Gender Equity, 30(2), 13-20. https://doi.org/10.1080/10130950.2016.1227542

NTV. (2012, May 6). Erdoğan'dan Suriyelilere: Zaferiniz uzak değil [From Erdogan to Syrians: Your victory is not far away]. Available at: https://www.ntv.com.tr/turkiye/erdogandansuriyelilere-zaferiniz-uzak-degil,eh4IpDgi200ApyeeBVB IdQ

Nyamnjoh, F. B. (2010). Racism, ethnicity and the media in Africa: Reflections inspired by studies of xenophobia in Cameroon and South Africa. Africa Spectrum, 45(1), 57-93. https://doi.org/10.1177/000203971004500103

Ozmete, E., Yildirim, H. and Duru, S. (2018). Yabancı düşmanlığı (zenofobi) ölçeğinin Türk kültürüne uyarlanması: Geçerlilik ve güvenirlik çalışması [Adaptation of the scale of xenophobia to Turkish culture: Validity and reliability study]. Sosyal Politika Çalışmaları Dergisi [Journal of Social Policy Studies], 40(2), 191-209. https://doi.org/ 10.21560/spcd.v18i39974.451063

Rutherford, J. (2007). After identity. Media\&Cultural Studies, 21(1), 5-18. https://doi.org/10.1080/10304310601103893

Sinclair, R. R. and Tetrick, L. E. (2000). Implications of item wording for hardiness structure, relation with neuroticism, and stress buffering. Journal of Research in Personality, 34(1), 1-25. https://doi.org/10.1006/jrpe.1999.2265

Sunata, U. (2019). Geçici koruma altındaki Suriyeli gençlerin geçim kaynaklarına erişimi araştırması [The research regarding the accessibility to sources of livelihood of Syrian youth who are under temporary protection]. STGM. Available at: https://www.stgm.org.tr/

Tönnies, F. (2019). Cemaat ve cemiyet [Community and society], E. Guler (trans.). Istanbul: Vakıfbank Kültür Yayınları [Vakifbank Cultural Publications].

van der Veer, K., Ommundsen, R., Yakusho, O. and Higler, L. (2011). Cross-national measure of fear-based xenophobia: Development of a cumulative scale. Psychological Reports, 109(1), 27-42. https://doi.org/10.2466/07.17.PR0.109.4.2742 